\title{
KOMBINERTE METODER
}

- et tredje paradigme i sykepleieforskningen?

Av Elsa Kaarbø, sykepleier og høgskolelektor, Høgskolelektor Høgskolen i Bergen. Avdeling for helse- og sosialfag. Institutt for sykepleie

\section{$>$ INNLEDNING}

I all forskning bør metodevalget bestemmes ut fra problemstilling. Hvilken fremgangsmåte kan gi svar på det som skal undersøkes? Tradisjonelt har forskere innen sykepleie måttet velge mellom såkalte kvalitative eller kvantitative tilnærminger. De representerer to forskjellige tenkemåter (paradigmer) med hver sine metoder. Enkelt sagt vil det kvalitative paradigmet stå for en induktiv, holistisk og subjektiv tilnærming som kan si noe om det kontekstuelle og særegne ved et fenomen. Kvantitativ forskning kjennetegnes ved hypotetiskdeduktiv metodologi hvor objektivitet og generaliserbarhet kan vise allmenne sammenhenger (1). Selv om disse to tenkemåtene er forskjellige og til tider har stått i et sterkt motsetningsforhold til hverandre, er de nå å betrakte som selvstendige, men komplementære innenfor de fleste fagområder (2, 3).

I nyere tid har forskere $(3,4,5)$ argumentert for at det er mulig å kombinere de to tilnærmingene i samme studie, og at dette noen ganger kan være det beste alternativet for kunnskapsutvikling. De omtaler denne muligheten, «mixed methods», som et tredje forskerparadigme som er sidestilt med de to andre. En annen benevnelse er «a third methodological movement»(6). Denne type tilnærming er i sterk vekst i USA og i England. Omtrent 18 prosent av britisk helseforskning i tidsrommet1994-2004 har benyttet «mixed methods research» (7). Et hovedargument er at utfordringene i helse- og sosialtjenestene ofte er sammensatte og dermed krever flere metoder enn én for å kunne belyse problemstillingene $(7,8)$.

Det blir skrevet artikler og bøker og holdt internasjonale konferanser om emnet. De to amerikanske tidsskriftene «Journal of Mixed Methods Research» og «International Journal of Multiple Research Approaches» er viktige formidlingskanaler for denne type forskning. Så langt jeg kan se er dette lite kjent innenfor sykepleieforskning i Norge. Jeg vil derfor prøve å definere begrepet og si noe om hvordan denne tilnærmingen praktisk kan gjennom- føres. Styrke og svakheter ved bruken av kombinerte metoder vil også bli drøftet.

\section{BEGREPSAVKLARING}

«Mixed methods» (også omtalt som «multi-method, mixed research or integrative research») er et begrep som er utviklet av engelske og amerikanske forskere: «A mixed methods research is a procedure for collecting, analysing, and 'mixing' both quantitative and qualitative research and methods in a single study to understand a research problem» (9 s. 552).

Den filosofiske overbygningen er pragmatisme. Forskeren bruker de metodene som synes å være nyttige for å finne svar på et spesielt forskningsspørsmål. Dette står i motsetning til metodologiske «purister» som hevder at man alltid skal arbeide innenfor enten et kvalitativt eller et kvantitativt paradigme (4). I denne artikkelen har jeg valgt å oversette «mixed methods» med begrepet «kombinerte metoder» og beskriver fire typer forskningsdesign innenfor denne type forskning (figur 1).

\section{$>$ TRIANGULERING 1}

Kvantitative og kvalitative data samles og analyseres samtidig eller parallelt. Kunnskapstilfanget ligger i blandingen og tolkningen av resultatene: «The purpose of a triangulation (or concurrent or parallel) mixed methods design is to simultaneously collect both quantitative and qualitative data, merge data, and use the results to understand a research problem» (9 s. 557).

Triangulering kan stimulere til utviklingen av kreative måter å samle inn data på og lede til fyldigere og rikere data. Det kan også føre til syntese eller integrasjon av teorier (10). Triangulering fører gjerne til at forskeren får flere innfallsvinkler i sin søken etter kunnskap. Mønstre som kan komme frem ved bruk av en metode, kan suppleres, bekreftes eller motsies av funn via andre metoder. Et eksempel kan være at man samler inn kvantitative og kvalitative data i et intervju, analyserer disse hver for seg, blander og 
tolker data og bruker resultatene til å svare på et forskningsspørsmål (11).

Men innsamlingen av forskjellige typer data er ressurskrevende. Kunnskap og ferdigheter til å kunne analysere og tolke resultatene, stiller store krav til forskeren, blant annet problemet med å transformere en type data til en annen for å integrere og sammenligne databasene. Dette kan løses ved at flere forskere med ulik bakgrunn, arbeider sammen i et forskerteam (forskertriangulering).

\section{> 2. INNLAGT KOMBINERTE METODER}

Dette designet ligner på triangulering, men med noen viktige unntak. Innenfor samme studie samles kvantitative og kvalitative data samtidig og analyseres hver for seg, men forskeren lar en form for data spille en støttende rolle til den andre formen for data. Designet kan ha en større kvantitativ komponent og en mindre, støttende kvalitativ komponent.

Metoden kan brukes ved korrelasjons-og intervensjonsforskning (eksperimenter). Kvantitative data kan for eksempel vise om et behandlingsopplegg har hatt noen virkning på deltakerne, mens kvalitative data vil kunne si noe om hvordan deltakerne opplevde intervensjonen. Forskeren kan dermed få svar på to ulike forskningsspørsmål: «In the embedded design analysis, the analyses of the quantitative and qualitative data are kept separate because the two data sets often reflect different questions» (9 s. 566).

Utfordringen ved dette designet er at det er vanskelig å kombinere de to databasene fordi data svarer på to forskjellige forskningsspørsmål. I tillegg vil det å introdusere kvalitativ datasamling i et eksperiment (eller en korrelasjonsstudie) kunne ha innflytelse på resultatet. For å unngå dette kan man samle kvalitative data på slutten av eksperimentet. Ellers vil mange av utfordringene være de samme som ved triangulering.

\section{> 3. FORKLARENDE KOMBINERTE METODER}

Her samles data i to omganger: «An explanatory mixed methods design (or a two-phase model) consists of first collecting quantitative data and then collecting qualitative data to help explain or elaborate on the quantitative results» (9 s. 560). Kvantitative data og resultater gir et generelt bilde av forskningsspørsmålet, mens en mer inngående analyse gjennom kvalitative data vil kunne nyansere, utvide og forklare det generelle bildet. I en survey (12) fikk man inn 1431 utfylte skjema og dybdeintervjuet deretter 12 av deltakerne. Studien ga to svar: Det ene (kvantitative data) viste forskjell mellom kvinner og menn når det gjaldt deltakelse i sosiale aktiviteter i nærmiljøet. Kvinner var mer aktive enn menn. Det andre (kvalitative data) bidro med beskrivelser av forskjellene.

I dette designet er datatypene likeverdige og står hver for seg. Det blir enklere for dem som lager designet og som gjennomfører studien, og lettere for dem som senere skal lese om den. En behøver ikke sette sammen eller integrere to ulike typer data. Men forskeren må ha ekspertise og ressurser til å samle begge typer data og bestemme hvilke aspekter av det kvantitative resultat som skal følges opp via den kvalitative delen. Dette er utfordrende.

\section{> 4. UTFORSKENDE KOMBINERTE METODER}

Her samles data i to omganger, de kvalitative først: «The purpose of an exploratory mixed methods design is the procedure of first gathering qualitative data to explore a phenomenon, and then collecting quantitative data to explain relationships found in the qualitative data» (9 s. 561). Dette designet egner seg godt der forskeren vil undersøke et fenomen eller lage et instrument (for eksempel et spørreskjema) og teste det. Gjennom dybdeintervju kan man identifisere tema og lage kategorier til et spørreskjema: «One advantage of this approach is that it allows the researcher to identify measures actually grounded in the data obtained from study participants $19 \mathrm{~s}$. 561). 
Men metoden krever omfattende datainnsamling og er tidkrevende blant annet fordi et instrument må testes ut før det kan brukes. Forskeren må også velge ut hvilke tema eller kategorier som skal overføres fra dybdeintervjuene til den kvantitative unders $\emptyset$ kelsen. Dette designet er mye brukt innenfor sosiologi og sosialantropologi.

Disse fire forskningsdesignene velges ut fra den problemstilling forskeren arbeider med. Ut fra et pragmatisk ståsted vil designet som synes mest nyttig være det aktuelle. Som en fellesnevner for de fire fremgangsmåtene vil jeg i korte trekk oppsummere forskningsprosessen innenfor kombinerte metoder (9 s. 568)

\section{Trinn 1. Bestemme om forskeren har forutset- ning for å bruke kombinerte metoder}

Første steget i et slikt forskningsdesign er å vurdere om det er gjennomførbart. Har forskeren tilstrekkelig med kunnskaper og ferdigheter til å samle data kvalitativt og kvantitativt, gjennomføre analyse og rapportere i tråd med krav til begge forskningstradisjonene? Man må også tenke gjennom hvordan andre forskere, utgivere, praktikere og så videre vil ta imot og verdsette den kompleksiteten som kombinerte metoder kan by på.

\section{Trinn 2. Identifisere et rasjonale for bruken av kombinerte metoder}

Forskeren må også kunne begrunne valget. Hvorfor er det hensiktsmessig å samle både kvalitative og kvantitative data i og samme studie? Er det slik at forskeren mener at bruken av begge typer data vil gi bedre svar på forskningsspørsmålet enn bruken av bare en type tilnærming vil kunne gi? En slik begrunnelse bør gis tidlig i en prosjektplan eller rapport.

\section{Trinn 3. Planlegge en datasamlingsstrategi og type forskningsdesign}

Her må forskeren bestemme hvordan data skal samles inn, og om kvalitative og kvantitative data skal være likestilte (veie like mye). Figur 1 viser ulik vektlegging og rolle innenfor de fire forskningsdesignene. Skal data samles inn samtidig eller parallelt eller skal de samles inn i flere faser? Det må også avgjøres hvilke typer data det dreier seg om (bilder, ord, fortellinger og så videre).

\section{Trinn 4. Utvikle forskningsspørsmål}

Avhengig av hvilket forskningsdesign man vil benytte ved kombinerte metoder, kan man lage spørsmål på forhånd eller underveis. Velger man triangulering, vil det være naturlig å lage spørsmålene på forhånd. Ved et tofase design, vil spørsmålene til andre fase ikke være laget tidlig i studien, men fremkomme underveis i prosessen.

\section{Trinn 5. Samle kvantitative og kvalitative data}

Datasamling skal skje slik prosedyrene er for innsamling av henholdsvis kvantitative og kvalitative data. Her er det ingen forskjell på kombinerte metoder og henholdsvis kvalitative eller kvantitative metoder. Kvantitative data kan samles og overføres til et dataprogram og der bli gjenstand for statistisk behandling. Kvalitative data som ord og tekster kan behandles slik for eksempel temabasert analyse krever. Bruken av kombinerte metoder som innbefatter innsamling av begge typer data, kan bli svært omfattende og tidkrevende.

\section{Trinn 6. Analysere data hver for seg eller parallelt}

Analysen vil avhenge av hvilket av de fire forskningsdesignene som er valgt. Data kan analyseres hver for seg, slik man vil gjøre ved forklarende og for utforskende design, mens man ved triangulering vil kreve at resultatene fra begge typer data blir integrert i analysen. Dette blir ofte vurdert som den vanskeligste delen innenfor kombinerte metoder, og det er utarbeidet retningslinjer for hvordan en slik analyse kan utføres (9).

\section{Trinn 7. Å rapportere funnene sammen eller enkeltvis}


Her kan man velge å skrive denne som en hel eller som en todelt rapport. Det avhenger av hvilket forskningsdesign man har valgt. Når man bruker triangulering, vil det være naturlig å skrive en hel, sammenhengende rapport. Her vil man finne resultatene fra henholdsvis kvantitative og kvalitative data, men blandingen og tolkningen av begge typer data dominerer fremstillingen. Integreringen av begge typer data gjenspeiles i hele forskningsprosessen og dermed også i rapporten

Velger man å skrive en todelt rapport, vil rapporten kunne inneholde en del hvor man spesifiserer forskningsspørsmålet og litteraturen. Deretter kommer en seksjon hvor man presenterer datasamling og tolkning hver for seg: en kvantitativ og en kvalitativ del.

\section{DISKUSJON}

Sykepleiepraksis krever at utøverne har kunnskaper, ferdigheter og holdninger som gjør dem i stand til å yte hjelp, ofte i svært komplekse situasjoner. Utvikling av kunnskap innenfor dette feltet krever ulike tilnærminger, og bruken av kombinerte metoder kan være en vei å gå. Den filosofiske overbygningen eller paradigmet, handler om en pragmatisk tilnærming til forskningsspørsmålene og kjennetegnes av metodologisk mangfold. Hensikten er ikke å erstatte de to andre tilnærmingene, men å dra nytte av styrken og forminske svakhetene ved begge.

En kritikk av kombinerte metoder er at man blander metodologi (eller paradigmer) og derfor kommer «skjevt ut» helt fra starten. En annen innvending er at det kan være vanskelig for en enkelt forsker å gjennomføre både kvalitativ og kvantitativ forskning. Det kan løses ved at flere forskere arbeider med samme forskningsspørsmål, men med ulik vinkling.

\section{$>$ KONKLUSJON}

Kombinerte metoder med sine ulike forskningsdesign er fremdeles i utvikling, og man diskuterer hvordan man skal forholde seg til denne type forskning. Diskusjonen retter seg først og fremst mot synet på paradigme og pragmatisme i forskningen: «Some of the details of mixed research remain to be worked out fully by research methodologists Iproblems of paradigm mixing, how to qualitatively analyse quantitative data, how to interpret conflicting results etc.)»(3 s. 22). Det er også en utfordring å få de etablerte forskningsmiljøene til å delta i debatten. Så langt jeg kan se vil denne type forskning være til stor nytte, ikke minst innenfor sykepleiefaget. Sammensatte problemstillinger i helse- og sosialsektoren krever flere forskjellige tilnærminger som bruken av kombinerte metoder kan bidra til.

\section{REFERANSER}

1. Befring E. Forskningsmetode med etikk og statistikk. 2.utg. Oslo: Det Norske Samlaget, 2007.

2. Grønmo S. Samfunnsvitenskapelige metoder. Bergen: Fagbokforlaget, 2004.

3. Johnson RB, Onwuegbuzie AJ. Mixed Methods Research: A Research Paradigm Whose Time Has Come. Educational Researcher, 2004; 33: 14-27.

4. Creswell JW. Research Design. Qualitative, Quantitative, and Mixed Methods Approaches. 2. ed. Thousand Oaks, CA: SAGE Publications, Inc. 2003.

5. Williamson GR. Illustrating triangulation in mixed-methods nursing research.

Nurse Researcher, 2005; 12: 7-18.

6. Tashakkordi A, Teddlie C. Handbook of Mixed Methods in Social \& Behavioural Research. Thousand Oaks, CA: SAGE Publications, Inc.; 2003.

7. O'Catain A, Murphy E, Nicholl J. Why, and how, mixed methods research is undertaken in health services research in England: a mixed methods study.

Health Services Research. 2007, 7:85.

8 Røykenes K. (2008) Metodetriangulering - et metodisk minefelt eller en berikelse av fenomener? Sykepleien Forskning 2008; 4: 224-226.

9. Creswell JW. Educational Research. Planning, Conducting, and Evaluating Quantitative and Qualitative Research. 3. ed. New Jersey: University of Nebraska-Lincoln; Pearson International Edition, 2008. 10. Johnson

RB, Onwuegbuzie AJ, Turner LA. Toward a Definition of Mixed Methods Research. Journal of Mixed Methods Research. SAGE Publications. 2007, (s. 112-133).

11. Kennett DJ, O'Hagan FT, Cezer D. Learned Resourcefulness and the Long-Term Benefits of a Chronic Pain Management Program. Journal of Mixed Methods Research. SAGE Publications. 2008, (s. 1-23).

12. Hodgkin S. Telling It All. A Story of Women's Social Capital Using a Mixed Methods Approach. Journal of Mixed Methods Research. SAGE Publications. 2008, (s. 296-316). 